Mukhlishotul Jannah

\title{
STRATEGI INOVASI PRODUK DALAM MENCAPAI KEUNGGULAN KOMPETITIF
}

\begin{abstract}
Abstrak
Kondisi persaingan bisnis yang makin kompetitif dan lingkungan bisnis yang dinamis dan penuh ketidakpastian menuntut perusahaan untuk mencari terobosan baru dan mengimplementasikan strategi yang sesuai dan selaras dengan perubahan lingkungan bisnis. Perusahaan harus mampu menciptakan, mengeksploitasi, dan mencapai keunggulan kompetitif dengan cara menciptakan nilai-nilai daya saing perusahaan yang lebih baik dibandingkan para pesaing. Untuk mencapainya, perusahaan harus mampu menerapkan strategi dan nilai-nilai yang berbeda dan tidak dapat ditiru oleh pesaingnya. Salah satu strategi tersebut adalah melalui inovasi. Inovasi merupakan salah satu kunci untuk dapat memenangkan persaingan.

Dengan melakukan inovasi, perusahaan berharap dapat menciptakan produk yang benar-benar baru atau lain dari yang sebelumnya atau membuat produk yang merupakan perbaikan dari produk yang telah ada sebelumnya. Dalam mengkonsumsi suatu produk, konsumen tidak hanya sebatas melihat pada nilai atau fungsi dari suatu produk yang dibutuhkan, tetapi konsumen juga memperhatikan apakah produk yang dipilih memiliki nilai tambah atau kelebihan dibandingkan dengan produk lain yang sejenis. Keinginan inilah yang harus dimengerti oleh produsen sebagai landasan untuk melakukan proses inovasi. Perkembangan inovasi yang berhasil akan menjadi strategi yang tepat untuk mempertahankan kedudukan produk di pasar.
\end{abstract}

Kata Kunci: Inovasi, keunggulan, kompetitif.

\section{Pendahuluan}

Semakin tingginya kompetisi dalam dunia industri membuat berbagai perusahaan berlomba untuk menciptakan keunggulan kompetitif melalui berbagai strategi agar perusahaan dapat bertahan hidup di tengah ketatnya persaingan. Persaingan dalam dunia bisnis hampir terjadi pada seluruh industri dan jasa, sehingga produsen berusaha agar produk atau jasa yang dihasilkan dapat diterima oleh konsumen bahkan sukses dipasaran. Dalam membeli suatu produk konsumen tidak langsung membeli begitu saja, akan tetapi mereka mengidentifikasi terlebih dahulu apa yang mereka inginkan. Apalagi jika konsumen benar-benar selektif dalam menentukan pilihan mana yang akan di beli.

Strategi yang cukup tepat yang dapat dilakukan perusahaan ditengah persaingan yang semakin tinggi adalah dengan mempertahankan pelanggan melalui peningkatan 
kepuasan pelanggan dan loyalitas konsumen. Sedangkan strategi untuk memperluas pasar dapat dilakukan dengan memasarkan produk-produk baru (melalui inovasi produk). Dengan inovasi akan menciptakan suatu produk baru yang dapat memberikan solusi yang lebih baik bagi pemecahan masalah yang dihadapi konsumen.

Suatu perusahaan akan memiliki keunggulan kompetitif jika konsumen dapat memberikan gambaran yang jelas mengenai kebutuhan konsumen. Suatu perusahaan akan memiliki keunggulan kompetitif jika konsumen menuntut atau menekan produsen untuk melakukan inovasi lebih cepat sehingga dapat mencapai keunggulan kompetitif yang lebih canggih dibandingkan dengan perusahaan lain.

Inovasi adalah proses kreatif untuk membuat objek-objek dan substansi yang baru yang berguna bagi manusia. Inovasi bisa diartikan sebagai proses mengadopsi "sesuatu" yang baru oleh siapapun yang mengadopsinya, dan sebagai proses menciptakan produk baru. Inovasi mencakup kreatifitas dalam menciptakan produk baru, jasa, ide atau proses baru. Dengan perkataan lain, inovasi bisa diartikan sebagai proses adaptasi produk, jasa, ide, atau proses baik yang sudah ada dalam organisasi maupun yang dikembangkan dari luar organisasi.

Pada dasarnya terdapat dua tipe inovasi yaitu inovasi proses dan inovasi produk. Inovasi proses memfokuskan pada metode-metode baru yang diimplementasikan dalam proses inovasi dengan cara menggunakan teknologi baru atau mengembangkan teknologi yang telah ada, misalnya adalah penerapan model bisnis perusahaan, strategi perusahaan, gaya kepemimpinan, dan budaya perusahaan. Sedangkan inovasi produk menitik beratkan pada pengenalan produk secara radikal dan modifikasi produk yang ada.

Inovasi produk menjadi semakin penting dan diakui keberadaannya sebagai satu strategi dalam merespon persaingan bisnis yang makin kompetitif dan memiliki pengaruh besar terhadap kinerja dan daya saing perusahaan. Melalui inovasi produk, para pengambil keputusan dapat memberikan keputusan untuk mengatasi permasalahan bisnis dan tantangan bisnis yang muncul dan memberikan dasar yang kuat untuk menjaga kelangsungan hidup dan mencapai kesuksesan perusahaan dalam jangka panjang.

Inovasi bagi sebuah perusahaan dengan skala kecil dan menengah harus diartikan sebagai segala usaha yang dilakukan untuk membuat perusahaan menjadi lebih efektif dan efisien, sehingga menghasilkan produk yang lebih baik dari pesaing dan dapat dijual dengan harga yang lebih kompetitif. Inovasi tersebut harus mampu membuat produk yang berbeda dimata konsumen, sehingga konsumen lebih tertarik membeli produk tersebut dibandingkan dengan produk pesaing.

Dalam mengkonsumsi suatu produk, konsumen tidak hanya sebatas melihat pada nilai atau fungsi dari suatu produk yang dibutuhkan, tetapi konsumen juga memperhatikan apakah produk yang dipilih memiliki nilai tambah atau kelebihan dibandingkan dengan produk lain yang sejenis. Keinginan inilah yang harus dimengerti oleh produsen sebagai landasan untuk melakukan proses inovasi. 
Perkembangan inovasi yang berhasil akan menjadi strategi yang tepat untuk mempertahankan kedudukan produk di pasar.

\section{Pengertian Inovasi dan Dimensi Inovasi}

Inovasi berasal dari kata latin, "innovation" yang berarti pembaruan dan perubahan. Kata kerjanya "innova" yang artinya memperbarui dan mengubah. Innovasi merupakan suatu perubahan yang baru menuju kearah perbaikan, yang lain atau berbeda dari yang sudah ada sebelumnya, yang dilakukan dengan sengaja dan berencana atau tidak secara kebetulan.

Inovasi sebagai perubahan organisasi. Inovasi mencakup kreatifitas dalam menciptakan produk baru, jasa, idea atau proses baru. ${ }^{2}$ Inovasi bisa diartikan sebagai proses adaptasi produk, jasa, ide, atau proses baik yang sudah ada dalam organisasi maupun yang dikembangkan dari luar organisasi. Secara umum inovasi memiliki makna proses mengadopsi "sesuatu" yang baru oleh siapapun yang mengadopsinya, dan sebagai proses menciptakan produk baru. Menurut Yusanto dan M.K. Widjayakusuma yang dikutip Nana Herdiana Abdurrahman, Seseorang dikatakan kreatif jika dia bisa membuktikan sebagai orang yang memang banyak menghasilkan karya yang relatif baru, kemampuan berkreasi dapat dikembangkan melalui pengalaman yang luas, terutama pengalaman melihat dan mengamati berbagai hal yang relatif baru. ${ }^{3}$

Thompson dalam Hurley dan Hult memberikan definisi bahwa inovasi adalah konsep yang lebih luas yang membahas penerapan gagasan, produk, atau proses yang baru. ${ }^{4}$ Inovasi sebagai sebuah mekanisme perusahaan untuk beradaptasi dalam lingkungan yang dinamis, oleh karena itu perusahaan dituntut untuk mampu menciptakan pemikiran-pemikiran baru, gagasan-gagasan baru dan menawarkan produk yang inovatif serta peningkatan pelayanan yang memuaskan pelanggan.

Dalam sisi lain produk inovasi didefinisikan sebagai proses dari penggunaan teknologi baru kedalam suatu produk sehingga produk tersebut mempunyai nilai tambah. Inovasi dapat dilakukan pada barang, pelayanan, atau gagasan-gagasan yang diterima oleh seseorang sebagai sesuatu yang baru, sehingga mungkin saja suatu gagasan telah muncul di masa lampau, tetapi dapat dianggap inovatif bagi konsumen yang baru mengetahuinya. Seringkali orang berpendapat bahwa dengan melakukan inovasi pada suatu hal maka seseorang telah melakukan perubahan yang bersifat positif yang mengarah pada kemajuan.

Ada dua konsep inovasi yaitu : (1) Keinovativan dan (2) Kapasitas untuk berinovasi. Keinovativan adalah pikiran tentang keterbukaan untuk gagasan baru sebagai sebuah aspek kultur perusahaan. Sedangkan kapasitas untuk berinovasi adalah kemampuan perusahaan untuk menggunakan atau menerapkan gagasan, proses, atau produk baru secara berhasil. Keinovativan dapat juga diterjemahkan sebagai kultur suatu perusahaan. Keinovativan ini dapat dilihat dari bagaimana sikap suatu perusahaan terhadap adanya suatu inovasi. 
Tujuan utama Inovasi adalah meningkatkan sumber-sumber tenaga, uang, dan sarana, termasuk struktur dan prosedur organisasi. Terutama sumber tenaga; seorang karyawan harus memenuhi beberapa elemen berikut ini agar dapat mengembangkan daya kreativitas dalam berinovasi, diantaranya rajin membaca, memerhatikan orang dan barang, mencatat hal-hal baru; bayak berpikir dan mencari ide/gagasan baru; memetik hikmah merantau/kunjungan/peninjauan di tempat lain; rajin bertanya dan mengikuti diskusi/seminar/lokakarya atau pelatihan ilmiah; yakin bahwa apa yang ada di dunia termasuk apa yang ada di sekitar pasti ada gunanya; berintuisi. ${ }^{5}$

Inovasi merupakan suatu konsep multidimensional yang terdiri dari empat dimensi yaitu, orientasi kepemimpinan perusahaan terhadap inovasi, tipe inovasi yang dilakukan, sumber inovasi dan investasi yang dibutuhkan dalam inovasi.

Orientasi kepemimpinan menunjukkan posisi perusahaan dalam pasar apakah perusahaan sebagai first-to-the-market, perusahaan sebagai pemain kedua second-tothe-market, atau late-entrant. Pemimpin bertanggung jawab dalam menentukan dan merumuskan strategi sesuai posisi perusahaan dalam pasar. Sebagai perusahaan dalam posisi first-to-the-market, perusahaan menitikberatkan pada implementasi inovasi proses dan inovasi produk untuk menghasilkan produk yang unik dan inovatif. Sebagai perusahaan second-to-the- market, perusahaan memonitor inovasi yang dilakukan perusahaan pesaing dan menirukan pesaing. Perusahaan sebagai late entrant hanya melakukan penjiplakan produk yang memiliki merek terkenal dan menjualnya pada harga yang rendah.

Dimensi inovasi kedua yaitu tipe inovasi mewakili kombinasi inovasi manufaktur yaitu proses yang dilakukan dan produk yang dihasilkan perusahaan. inovasi proses menekankan pada metode-metode baru dalam pengoperasian dengan cara membuat teknologi baru atau mengembangkan teknologi yang telah ada. Sedangkan inovasi produk merupakan hasil dari penciptaan dan pengenalan produk secara radikal atau modifikasi produk yang telah ada. Ketidakpastian teknologi, kurangnya dukungan manajer senior, kurangnya sumber daya, dan manajemen proyek yang jelek akan menghalangi pencapaian tujuan pengembangan produk. Pemilihan tipe inovasi dipengaruhi oleh investasi yang dimiliki perusahaan, dan pada akhirnya akan mempengaruhi kinerja perusahaan.

Dimensi inovasi ketiga adalah sumber inovasi yang menjelaskan pelaksanaan aktivitas inovasi, apakah ide inovasi berasal dari internal perusahaan, eksternal perusahaan atau keduanya. Sumber inovasi internal memiliki makna bahwa perusahaan mempercayakan untuk melakukan inovasi baik pada proses atau produk pada usaha bagian riset dan pengembangan. Sedangkan sumber inovasi eksternal memiliki makna perusahaan akan melakukan inovasi dengan cara membeli, persetujuan lisensi, akuisisi perusahaan lain atau kerjasama ( joint ventures ) dengan supplier, pelanggan atau perusahaan lain.

Dimensi inovasi keempat yaitu tingkat investasi mencakup investasi baik dalam hal investasi keuangan, teknologi maupun investasi sumber daya manusia. Investasi keuangan meliputi pengeluaran untuk proyek riset dan pengembangan , dan 
pembelian suatu inovasi pada produk yang telah dikembangkan di tempat lain. Investasi teknologi adalah pengeluaran untuk peralatan, infrastruktur, fasilitas dasar yang dibutuhkan untuk melakukan inovasi. Investasi dibidang sumberdaya manusia termasuk diantaranya gaji, pelatihan dan biaya-biaya lain yang berhubungan dengan pengembangan staf.

Di dalam perspektif pemasaran, maka inovasi harus mampu menciptakan harga yang lebih kompetitif (price), produk yang lebih baik (product), konsumen mudah memperoleh produk tersebut (place), perusahaan mampu mengkomunikasikan produk sehingga konsumen mengenal produk tersebut. ${ }^{6}$

Inovasi akan menciptakan produk yang berbeda dari pesaing, sehingga perusahaan dapat melakukan "product differentiation" kepada konsumen. Perusahaan yang terus menerus mampu menciptakan "product differentiation" melalui inovasi dan mampu mengkomunikasikan produk baru tersebut kepada konsumen sehingga konsumen memandang produk tersebut sebagai produk yang berbeda dari produk pesaing maka pada hakekatnya perusahaan tersebut telah melakukan penetrasi pasar dan memenangkan persaingan.

Inovasi yang menghasilkan produk baru dengan karakteristik kualitas lebih baik dan harga yang lebih rendah dari pesaing akan menarik konsumen yang sensitif terhadap harga. Konsumen tersebut akan meninggalkan produk pesaing dan beralih kepada produk yang inovatif tersebut.

Menurut Hendro, ada jenis-jenis inovasi yang sering digunakan oleh pelakupelaku usaha yang cerdas dalam bisnisnya, yaitu :

1. Inovasi Produk; meliputi isi (rasa, kualitas, dan lain-lain), dan kemasan (pembungkus, tulisan, warna, sistem buka tutupnya, bentuknya, dan lain-lain).

2. Inovasi Marketing; meliputi cara menjual, cara mendistribusikan, cara memasarkannya, cara menciptakan permintaan, dan lain-lain.

3. Inovasi Proses; meliputi proses penciptaan produk, proses produksi, proses teknologi pengemasannya, proses riset dan pengembangannya, proses menciptakan mesin baru, dan lain-lain.

4. Inovasi Teknikal; meliputi teknik desain, teknik pengawasannya, teknik pengerjaannya, dan lain-lain.

5. Inovasi Administrasi; meliputi penyimpanan data, pembuatan dan pengumpilan data. $^{7}$

\section{Faktor Yang Mendukung Keberhasilan Inovasi}

Menurut James Brian Quinn yang dikutip oleh Hendro, ada beberapa faktor yang mendukung keberhasilan dari sebuah inovasi yaitu harus berorientasi pasar, mampu meningkatkan nilai tambahan perusahaan, punya unsur efisiensi dan efektivitas, harus sejalan dengan visi dan misi perusahaan, dan harus bisa ditingkatkan lagi. ${ }^{8}$

Harus berorientasi pasar; Banyak inovasi yang sekedar pemecahan masalah kreatif tetapi tidak bersifat dan mempunyai keunggulan bersaing di pasar. Hubungan 
inovasi dengan pasar yang didalamnya ada 5C, yaitu Competitor (pesaing), Competition (persaingan), Change of competition (perubahan persaingan), Change driver (penentu arah perubahan), dan Customer behaviour (perilaku konsumen).

Mampu meningkatkan nilai tambahan perusahaan; Ada nilai tambah (value added) sehingga bisa menjadi dongkrak pertumbuhan dan perkembangan perusahaan.

Punya unsur efisiensi dan efektivitas; Tanpa dua faktor ini, yaitu faktor efisiensi dan faktor efektivitas dari sebuah inovasi yang ditemukan maka inovasi tersebut tidak mempunyai arti atau dampak yang berarti bagi kemajuan perusahaan.

Inovasi harus sejalan dengan visi dan misi perusahaan agar tidak menyimpang dari arah pertumbuhan usaha.

Inovasi harus bisa di inovasikan lagi sehingga terjadi inovasi yang berkelanjutan (continuous improvement) sehingga menumbuhkan perusahaan menjadi lebih baik dan lebih berkembang.

Selanjutnya masih menurut Hendro, ada beberapa sumber yang mendorong terjadinya sebuah inovasi, yaitu:

1. Perbedaan (gap) antara permintaan (demand) dan penawaran (supply).

Di suatu Negara yang mempunyai budaya tertentu, biasanya jika penawaran barang/produk tidak sesuai dengan kondisi permintaan yang ada, maka kejadian ini bisa memunculkan sebuah inovasi.

2. Penciptaan permintaan karena kecenderungan (kecenderungan).

Adanya kecenderungan pola hidup masyarakat Indonesia yang menyukai produk instan, maka muncullah produk-produk lain yang mengikuti tren tersebut.

3. Perubahan (change).

Setiap perubahan pasti diikuti sang motivator untuk dimanfaatkan, misalnya perubahan ekonomi, perubahan teknologi, perubahan sosial dan lain-lain.

4. Masalah yang belum terpecahkan dalam jangka waktu yang lama.

Terkadang masalah yang diselesaikan dengan cara pemecahan masalah kreatif saja belum tentu bisa memecahkan masalah dalam jangka waktu yang lama atau dapat menghilangkan masalah.

5. Inovasi yang ditujukan untuk mengganti inovasi produknya sendiri.

Hampir sebagian besar industri berteknologi tinggi menggunakan prinsip ini agar produknya bisa diganti dengan produk yang baru diluncurkan sehingga masih bisa menjadi pimpinan pasar. ${ }^{9}$

Ada beberapa cara yang dapat ditempuh untuk menghasilkan produk yang inovatif, yaitu dengan cara :

1. Mengembangkan atribut produk baru.

2. Mengembangkan beragam tingkat mutu.

3. Mengembangkan model dan ukuran produk.

Produk inovasi dapat gagal karena banyak faktor, misalnya tidak menawarkan desain yang unik atau salah memperkirakan persaingan merupakan kesalahan yang umum terjadi. Kadang-kadang gagasannya sendiri sebenarnya baik tetapi terletak pada desain dan efisiensi biayanya jauh lebih tinggi dari yang semula diperkirakan. 
Dengan adanya inovasi produk maka akan memberi nilai tambah dibanding produk sejenis (keunggulan produk), sehingga akan meningkatkan penjualan.

Keunggulan kompetitif suatu produk merupakan salah satu faktor penentu dari kesuksesan produk baru. ${ }^{10}$ Sehingga suatu produk inovasi harus mempunyai keunggulan dibandingkan dengan produk lain yang sejenis. Keunggulan produk baru sangat penting dalam lingkungan pasar global yang sangat kompetitif. Keunggulan tersebut tidak lepas dari pengembangan produk inovasi yang dihasilkan sehingga akan mempunyai keunggulan di pasar yang selanjutnya akan menang dalam persaingan.

Li dan Calantone berpendapat bahwa keunikan pada suatu produk diartikan sebagai atribut penting dari keunggulan produk tersebut, yang dipengaruhi oleh daya inovatif serta teknologi yang tinggi, sehingga dapat dihasilkan produk sesuai dengan keinginan konsumen. ${ }^{11}$

Perusahaan diharapkan bisa memuaskan keinginan konsumen dengan membuat produk yang superior. Keunggulan produk baru dapat diwujudkan apabila desainnya unik, kebaruan serta adanya efisiensi dalam biaya. Keberhasilan bisnis perusahaan akan dapat dicapai bila perusahaan dapat dengan cepat bereaksi dengan kondisi pasar baru dan kebutuhan pelanggan. Selain itu perusahaan dapat secara berkesinambungan mencari solusi yang kreatif serta peningkatan secara terus-menerus dalam menghasilkan produk. Perusahaan harus beradaptasi serta berinovasi secara terus menerus. Inovasi produk itu sendiri dapat dipengaruhi selain orientasi pasar juga teknologi.

\section{Keunggulan Bersaing Berkelanjutan}

Pemilik dan para pemangku kepentingan perusahaan (manajer, karyawan, pelanggan, pemasok, mitra, pemerintah, dan sebagainya) berharap perusahaan dapat memberikan manfaat sebesar-besarnya dalam jangka panjang. Mereka mendambakan perusahaan dapat bertahan, mampu menghadapi persaingan dan tumbuh berkembang dengan memanfaatkan berbagai peluang bisnis. Dengan kata lain, perusahaan diharapkan mendapatkan dan mempertahankan keunggulan bersaing secara berkelanjutan (sustainable competitive advantage). Perusahaan seperti inilah yang dinilai mampu menghasilkan keuntungan dan memiliki aset yang jauh melebihi pemain di industrinya. Perusahaan tersebut juga mampu bertahan menghadapi persaingan selama puluhan tahun dan tumbuh memanfaatkan berbagai peluang.

Keunggulan bersaing (Competitive Advantage) adalah jantung kinerja perusahaan dalam pasar bersaing. Keunggulan bersaing pada dasarnya tumbuh dari nilai atau manfaat yang diciptakan oleh perusahaan bagi para pembelinya yang lebih dari biaya yang harus dikeluarkan untuk menciptakannya. Nilai atau manfaat inilah yang sedia dibayar oleh pembeli, dan nilai yang unggul berasal dari penawaran harga yang lebih rendah ketimbang harga pesaing untuk manfaat setara atau penawaran manfaat unik yang melebihi harga yang ditawarkan. ${ }^{12}$ 
Inovasi merupakan suatu alat untuk kelangsungan hidup perusahaan, bukan hanya untuk pertumbuhan dalam hal kinerja tetapi juga kemenangan persaingan dalam hal keunggulan bersaing berkelanjutan. ${ }^{13}$ Perusahaan dikatakan memiliki keunggulan bersaing jika memiliki biaya lebih rendah dibandingkan pesaing, memiliki produk atau proses yang lebih baik, sukses menjalankan strategi fokus segmen pasar tertentu. Keunggulan bersaing berkelanjutan adalah sebagai kemampuan untuk mendapatkan keuntungan di atas normal dalam jangka panjang (sustain above normal return).

Perusahaan dikatakan memiliki keunggulan yang berkesinambungan hanya bila konsumen merasakan adanya perbedaan antara produk perusahaan dan pesaingnya, perbedaan tersebut muncul karena adanya gap kapabilitas, dan gap tersebut dapat dipertahankan. Strategi dalam mencapai keunggulan bersaing juga dapat didefinisikan dalam beberapa tingkatan, yaitu:

1. Corporate strategy, yang berkaitan dengan alokasi sumber daya di antara berbagai bisnis atau divisi dalam perusahaan.

2. Business Strategy, yang terdapat pada tingkatan bisnis atau divisi tertentu, yang khususnya berkaitan dengan posisi persaingan (competitive advantage).

3. Functional strategy, yang terbatas pada tindakan-tindakan fungsi-fungsi tertentu dalam suatu bisnis (misalnya fungsi pemasaran, personalia, keuangan dan lainnya).

Untuk menghadapi kekuatan persaingan, Porter mengemukakan perlunya strategi yang dikenal dengan nama strategi generic yang merupakan cara mendasar bagi perusahan untuk mencapai profitabilitas di atas rata-rata industri dengan memiliki sustainable competitive advantage. ${ }^{14}$

Strategi generik terdiri dari 3 macam yaitu:

1. Strategi keunggulan biaya menyeluruh; mencapai keunggulan biaya menyeluruh dalam industri melalui seperangkat kebijakan fungsional yang ditujukan kepada sasaran pokok.

2. Strategi diferensiasi, adalah diferensiasi produk atau jasa yang ditawarkan perusahaan, yaitu menciptakan sesuatu yang dirasakan oleh keseluruhan industri sebagai hal yang unik. Pendekatan untuk melakukan diferensiasi dapat bermacama-macam bentuknya; citra rancangan atau merek (brand Image), teknologi, karakteristik khusus, pelayanan pelanggan, jaringan penyalur, atau dimensi-dimensi lainnya.

3. Strategi fokus, adalah memusatkan (focus) pada kelompok pembeli, segmen lini produk, atau pasar geografis tertentu.

Penjelasan lebih lanjut mengenai strategi yang dapat dilaksanakan dalam mempertahankan keunggulan bersaing secara berkelanjutan, yaitu cost leadership strategy, differentiation strategy, dan market segmentation strategies adalah sebagai berikut:

a. Cost Leadership Strategy 
Strategi ini menekankan pada efisiesi. Dengan volume produksi yang tinggi produk standar, perusahaan berharap dapat memanfaatkan economies of scale dan experience curve effects. Produk standar tanpa tambahan apapun yang dapat diproduksi pada biaya yang relatif rendah dan dapat tersedia bagi seluas mungkin pelanggan. Strategi ini dapat dicapai dengan syarat perlu pencarian secara kontinyu pengurangan harga dari seluruh aspek bisnis. Ini terkait dengan strategi distribusi yang mampu menyediakan distribusi produk seluas mungkin. Strategi promosi yang sering digunakan meliputi upaya menyembunyikan fitur-fitur produk yang berbiaya rendah. Keberhasilan strategi ini membutuhkan pertimbangan keunggulan market share yang mampu mengakses bahan baku, komponen, tenaga kerja, dan input penting lainnya. Tanpa keunggulan tersebut, strategi ini akan mudah ditiru oleh pesaing.

\section{b. Differentiation Strategy}

Diferensiasi meliputi penciptaan suatu produk yang unik. Keunikan fitur atau manfaat yang akan memberikan nilai superior bagi pelanggan akan menjamin keberhasilan strategi diferensiasi. Pelanggan melihat produk sebagai produk yang tak tertandingi dan tak ada yang menyamai, sehingga elastisitas harga cenderung dapat dikurangi dan pelanggan cenderung menjadi loyal terhadap brand. Maka ini dapat menghindarkan diri dari persaingan. Akan tetapi strategi ini perlu tambahan biaya terkait dengan biaya penciptaan fitur produk yang berbeda dan oleh karenanya perlu strategi harga premium.

Dalam strategi diferensiasi, terdapat beberapa syarat sukses yang harus dimiliki oleh perusahaan, yaitu:

1. Kekuatan dalam riset dan pengembangan

2. Keahlian dalam rekayasa produk

3. Kemampuan kreativitas yang tinggi

4. Memiliki kerjasama yang baik dalam saluran distribusi

5. Memiliki keahlian yang kuat dalam pemasaran

6. Insentif sebagian besar didasarkan pada langkah-langkah subjektif

7. Mampu berkomunikasi pentingnya karakteristik produk yang berbeda

8. Pengelolaan secara terus-menerus terhadap stress dan inovasi

9. Merekrut orang-orang yang memiliki keahlian tinggi dan kreatif

\section{c. Market Segmentation Strategies-Focus Strategy}

Dalam strategi ini perusahaan berkonsentrasi pada seleksi pasar sasaran yang spesifik atau disebut juga dengan focus strategy or niche strategy. Dengan memfokuskan usaha-usaha pemasaran pada 1 atau 2 segmen pasar sempit dan menyesuaikan bauran pemasaran pada pasar spesifik ini maka diharapkan perusahaan dapat memenuhi kebutuhan pasar sasaran secara lebih baik. Perusahaan mencari keuntungan dengan meraih keunggulan kompetitif melalui efektifitas bukan efisiensi. 
Strategi ini sesuai bagi perusahaan yang relatif kecil dan umumnya menggunakan strategi pemasaran perang gerilya.

Porter lebih lanjut menjelaskan tentang generic strategies ditentukan melalui dua dimensi, yaitu: strategic scope dan strategic strength.

1. Strategic scope adalah dimensi dari sisi permintaan (demand side), yang ditentukan oleh ukuran dan komposisi pasar yang akan dijadikan sebagai target.

2. Strategic strength adalah dimensi dari sisi penawaran (supply side), yang dapat dilihat dari: kekuatan atau kompetensi inti perusahaan. Yang diidentifikasikan oleh dua kompetensi terpenting, yakni: product differentiation dan product cost (efficiency).

Perusahaan yang melakukan inovasi berkelanjutan dipandang sebagai sumber keunggulan bersaing. Dalam mencapai keunggulan bersaing, ada beberapa hal lain yang bisa menjadi ukuran, yaitu keunggulan sumber daya, keunggulan posisi, dan keunggulan nilai bagi pelanggan. Keunggulan sumber daya yang terdiri dari keunggulan keahlian dan keunggulan dalam bahan baku serta kinerja pemasaran dan modal. Keunggulan posisi yang terdiri dari keunggulan biaya relatif rendah dan keunggulan nilai bagi pelanggan yaitu nilai yang berbeda dengan yang lain dan tidak mudah digantikan.

Sesuai dengan pendapat Porter, keunggulan bersaing dapat diperoleh dari sumber daya dan modal yaitu kekuatan dan kelemahan kinerja pemasaran, sedangkan modal diartikan sebagai kemampuan perusahaan didalam mengelola sumberdaya yang dimiliki untuk bekerja sama seperti tim kerja dalam satu departemen, atau dengan kata lain tinggi rendahnya kinerja pemasaran akan berpengaruh kepada tinggi rendahnya keunggulan bersaing perusahaan. Keunggulan posisi terdiri dari keunggulan biaya relatif rendah dan keunggulan nilai bagi pelanggan. ${ }^{15}$ Dalam kondisi lingkungan yang berubah dengan cepat, keunggulan bersaing ditentukan oleh kreativitas dan inovasi yang dapat memuaskan keinginan pelanggan secara lebih baik dari pada pesaing.

Setiap perusahaan yang bersaing dalam suatu industri mempunyai strategi bersaing, eksplisit atau implisit. Strategi ini mungkin dikembangkan secara eksplisit melalui proses perencanaan atau mungkin juga telah berkembang secara implisit melalui kegiatan-kegiatan dari berbagai departemen fungsional perusahaan. Tetapi gabungan dari pendekatan-pendekatan departemental ini jarang sekali yang merupakan strategi terbaik.

Pada dasarnya pengembangan strategi bersaing adalah mengembangkan formula umum mengenai bagaimana bisnis akan bersaing, apa sebenarnya yang menjadi tujuannya, dan kebijakan apa yang akan diperlukan untuk mencapai tujuantujuan tersebut. Strategi bersaing adalah kombinasi antara tujuan akhir yang diperjuangkan perusahaan dengan alat (kebijakan) dimana perusahaan berusaha sampai ke sana.

Keunggulan bersaing sebagai strategi benefit dari perusahaan yang melakukan kerjasama untuk berkompetisi lebih efektif dalam market place. ${ }^{16}$ Strategi harus 
didesain untuk mewujudkan keunggulan bersaing yang terus menerus, sehingga perusahaan dapat mendominasi pasar lama maupun pasar baru. Hal terpenting dalam mencapai kesuksesan strategi yang diterapkan adalah dengan mengidentifikasi asset perusahaan yang sesungguhnya, dalam hal ini adalah tangible dan intangible resources yang membuat organisasi itu unik.

Menurut Triono, sumberdaya dan kapabilitas perusahaan merupakan sumber keunggulan bersaing berkelanjutan. Hanya sumberdaya dan kapabilitas yang memiliki kriteria valuable, rare, in-imitable, non-substitutable, exploited by company (VRISE) yang dapat menjadi sumber keunggulan bersaing berkelanjutan. ${ }^{17}$

Valuable berarti sumberdaya dan kapabilitas yang dimiliki memungkinkan perusahaan menerapkan strategi yang dapat meningkatkan efektivitas dan efisiensi organisasi. Rare artinya sumberdaya dan kapabilitas tersebut jarang dimiliki oleh para pesaing. In-imitable artinya sumberdaya dan kapabilitas sulit ditiru oleh pesaing atau memerlukan biaya sangat besar atau waktu yang lama untuk meniru. Nonsubstitutable yakni sumberdaya dan kapabilitas yang dimiliki sulit digantikan dengan sumberdaya atau kapabilitas lain. Misalnya pola hubungan antara Bank BRI dengan para nasabah usaha mikro sulit diganti dengan pola $e$-banking.

Selain itu perusahaan harus mampu memanfaatkan dan memelihara sumberdaya dan kapabilitas yang menjadi sumber keunggulan bersaing (exploited by company).

Dengan mengetahui sumberdaya dan kapabilitas yang menjadi sumber keunggulan bersaing, perusahaan dapat mengembangkan sumberdaya dan kapabilitas unggulan secara lebih terencana dan efektif.

Dalam mengidentifikasi sumberdaya dan kapabilitas unggulan kita perlu memahami kunci-kunci sukses bersaing dalam suatu industri. Perlu dipahami dengan memiliki sumberdaya dan kapabilitas unggulan tidak otomatis perusahaan memiliki keunggulan bersaing. Sumberdaya dan kapabilitas unggulan tersebut harus dimanfaatkan sedemikian rupa melalui implementasi strategi bisnis yang tepat.

Lingkungan bisnis selalu mengalami perubahan, baik eksternal maupun internal. Sehingga menyebabkan perubahan kunci sukses di suatu industri dan akhirnya juga menyebabkan keusangan pada sumber keunggulan bersaing. Dengan demikian perusahaan harus selalu memperbaharui sumberdaya dan kapabilitas unggulannya sesuai dengan perubahan kunci sukses di industri.

Perusahaan harus memiliki kemampuan kapabilitas dinamik (dynamic capability) yakni kemampuan untuk membentuk ulang, mengkonfigurasi, dan merekonfigurasi sumberdaya dan kapabilitas perusahaan sehingga dapat merespon perubahan teknologi dan pasar. Sebagai contoh, Apple Inc. adalah perusahaan telah berhasil melakukan inovasi yang dapat memenangkan persaingan.

Apple Inc. adalah ahlinya inovasi. Dimulai dengan gebrakan yang luar biasa hebat melalui iPod, Apple menjungkirbalikkan dominasi Sony Walkman yang selama bertahun-tahun mendominasi pasar hiburan. Sony yang selama puluhan tahun merajai pasar, akhirnya harus mengikuti permainan dan kompetisi yang diciptakan oleh Apple dengan iPodnya. ${ }^{18}$ 
Inovasi kedua adalah saat Apple mengumumkan bahwa mulai tahun 2006, Apple memulai transisi untuk menggunakan prosesor Intel, dan akan digunakan sepenuhnya pada tahun 2007 untuk komputer Macintosh. Ini perkembangan menarik mengingat selama ini Apple adalah salah satu pengguna setia prosesor milik IBM. Apple dengan Macintosh selama ini cenderung melakukan strategi niche market, dengan membidik kalangan desainer dan industri grafis. Mereka membuat hardware komputer sendiri, program dan aplikasinyapun dibuat khusus untuk kalangan mereka. Yang jelas, keluar dari mainstream utama yang dikeluarkan oleh Microsoft.

Dengan strategi ini, memang menjadikan pengguna Apple satu komunitas eksklusif yang cukup loyal. Loyalitas itu terbangun dan dibentuk oleh Apple dengan membuat aplikasi yang user friendly, lengkap, dan juga didukung oleh desain komputer yang unik dan berbeda dari desain komputer secara umum.

Namun demikian, strategi ini membuat komputer buatan Apple menjadi terbatas dan terjual hanya pada kalangan tertentu. Karena itulah, pergantian prosesor dari IBM ke Intel membawa konsekuensi yang sungguh luas, di antaranya tentu saja kolaborasi Apple-Microsoft. Dengan membuka diri terhadap sistem operasi Microsoft, Apple membuka pasar yang jauh lebih luas bahwa komputer buatan Apple, terutama laptopnya, Macbook, bisa digunakan oleh siapa saja. Macbook yang dulunya eksklusif hanya untuk perangkat lunak buatan Apple, sekarang ini bisa juga diinstall Windows yang buatan Microsoft.

Inovasi sangatlah penting untuk bisa bersaing sehat dengan para pesaing lain. Untuk menghasilkan suatu produk yang bisa diterima masyarakat dengan baik, diperlukan adanya konsep strategi inovasi yang matang untuk mencapai keunggulan bersaing.

Produk yang dibuat agar bisa mempunyai keunggulan bersaing tidak harus selalu unik, karena produk yang unik saja belum tentu bisa diterima oleh pasar karena tidak sesuai dengan harapan konsumen.

\section{Penutup}

Dalam berinovasi perusahaan harus mampu menciptakan, mengeksploitasi, dan mencapai keunggulan kompetitif dengan cara menciptakan nilai-nilai daya saing perusahaan yang lebih baik dibandingkan para pesaing. Untuk mencapainya, perusahaan harus mampu menerapkan strategi dan nilai-nilai yang berbeda dan tidak dapat ditiru oleh pesaingnya.

Strategi tersebut diantaranya adalah strategi keunggulan biaya menyeluruh (cost leadership strategy), strategi diferensiasi (differentiation strategy) dan strategi fokus (market segmentation strategies).

Inovasi bermula dari hal yang tampak sepele dengan membuka mata dan telinga, mendengarkan aspirasi atau keluhan konsumen, karyawan, lingkungan, dan masyarakat.Subyek penerapan inovasi sendiri bisa individu, kelompok atau perusahaan. Artinya bisa terjadi dalam perusahaan ada individu atau kelompok yang sangat brilliant dan inovatif, tetapi yang ideal adalah perusahaan menjadi tempat 
yang terlembagakan bagi orang-orang yang terkumpul untuk mengeksploitasi ide-ide baru.

\section{Catatan Akhir:}

${ }^{1}$ Hendro, Dasar-Dasar Kewirausahaan, (Jakarta: Erlangga, 2011), h.121.

${ }^{2}$ Gilbert J.T., Choosing an Innovation Strategy; Theory and Practice, Business Horizon, NovemberDesember 1994, h.16.

3 Nana Herdiana Abdurrahman, Manajemen Bisnis Syariah dan kewirausahaan, (Pustaka Setia :Bandung, 2013), h.181.

${ }^{4}$ Hurley, Robert F and Hult,G, Tomas M, Innovation, Market Orientation and Organization Learning: An Intergation and Market Empirical Examination, (Journal of Marketing, July, 1998).

${ }^{5}$ Nana Herdiana Abdurrahman, Manajemen Bisnis Syariah dan kewirausahaan,...h.182.

${ }^{6}$ Ujang Sumarwan, Inovasi Produk, Kepuasan Konsumen, dan Loyalitas Konsumen Sebagai Penentu Pertumbuhan Perusahaan, Jurnal Sains Pemasaran Indonesia, Vol.1, Mei.

${ }^{7}$ Hendro, Dasar-Dasar Kewirusahaan, Erlangga, Jakarta, 2011, h.124

${ }^{8}$ Hendro, Dasar-Dasar Kewirusahaan, ..., h. 122

${ }^{9}$ Hendro, Dasar-Dasar Kewirusahaan... h.122.

${ }^{10}$ Song, X. Michael and Parry, Mark E, A Cross-National Comparative Study of New Product Development Processes, (Japan and the United States : Journal of Marketing, Vol. 61, April 1997), h.64.

11 Tiger Li and Roger J Calantone, The Impact of Market Knowledge Competence on New Product Advantage: Conceptualization and Empirical Examination, (Journal of Marketing, Vol. 62, October, 1998), h.17.

12 Michael. E. Porter, Keunggulan Bersaing, Menciptakan dan Mempertahankan Kinerja Unggul, (Jakarta : Erlangga, 1993), h.3.

${ }^{13}$ Han, Jin K, Namwoom, Srivastava, Rajendra K, Market Orientation and Organization Performance: Is Innovation a Missing Link?, (Journal of Marketing, Ockober. Vol.6, No.4, 1998), h.30.

${ }^{14}$ Michael. E. Porter, Keunggulan Bersaing, Menciptakan dan Mempertahankan Kinerja Unggul, ..., h.35.

15 Porter, Michael. E, Keunggulan Bersaing, Menciptakan dan Mempertahankan Kinerja Unggul,...,h.3.

16 Prakosa, Pengaruh Orientasi Pasar, Inovasi Dan Orientasi Pembelajaran Terhadap Kinerja perusahaan untuk mencapai keunggulan Bersaing Berkelanjutan, (Jurnal Marketing, Vol 2 No. 1. 2006)

${ }^{17}$ Triono Saputro, Mendapatkan keunggulan bersaing berkelanjutan http://manajemenppm.wordpress.com/, diunduh pada 16 April 2013, pukul 09.00 WIB.

${ }^{18}$ Akbar Zainudin, Inovasi Untuk Keunggulan Bersaing, http://ekonomi.kompasiana.com/bisnis/, 5 Spetember 2010. 


\section{DAFTAR PUSTAKA}

Abdurrahman, Nana Herdiana, Manajemen Bisnis Syariah dan kewirausahaan, Bandung : Pustaka Setia, 2013.

Gilbert J.T.,Choosing an Innovation Strategy; Theory and Practice, Business Horizon, November-Desember 1994.

Han, Jin K, Namwoom, Srivastava, Rajendra K, Market Orientation and Organization Performance : Is Innovation a Missing Link?, Journal of Marketing, Ockober. Vol.6, No.4, 1998,

Hendro, Dasar-Dasar Kewirausahaan, Jakarta : Erlangga, 2011.

Hurley, Robert F and Hult,G, Tomas M, Innovation, Market Orientation and Organization Learning: An Intergation and Market Empirical Examination ${ }_{2}$ Journal of Marketing, July, 1998.

Li, Tiger and Calantone, Roger J, The Impact of Market Knowledge Competence on New Product Advantage: Conceptualization and Empirical Examination, Journal of Marketing, Vol. 62, October, 1998.

Porter, Michael. E., Keunggulan Bersaing, Menciptakan dan Mempertahankan Kinerja Unggul, Jakarta : Erlangga, 1993.

Prakosa, Pengaruh Orientasi Pasar, Inovasi Dan Orientasi Pembelajaran Terhadap Kinerja perusahaan untuk mencapai keunggulan Bersaing Berkelanjutan, Jurnal Marketing, Vol 2 No. 1. 2006

Saputro, Triono, Mendapatkan keunggulan bersaing berkelanjutan http://manajemenppm.wordpress.com/, diunduh pada 16 April 2013, pukul $09.00 \mathrm{WIB}$.

Song, X. Michael and Parry, Mark E, A Cross-National Comparative Study of New Product Development Processes, Japan and the United States : Journal of Marketing, Vol. 61, April 1997.

Sumarwan, Ujang, Inovasi Produk, Kepuasan Konsumen, dan Loyalitas Konsumen Sebagai Penentu Pertumbuhan Perusahaan, Jurnal Sains Pemasaran Indonesia, Vol.1, Mei. 


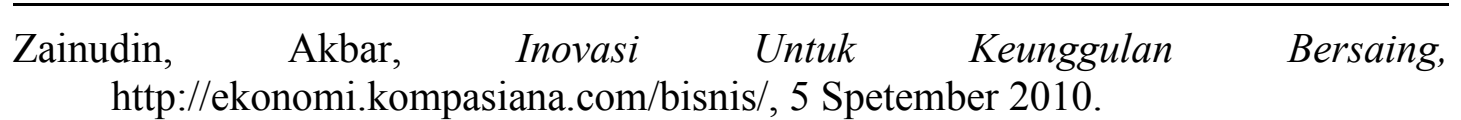

Mukhlisotul Jannah, dosen pada Fakultas Syari'ah dan Ekonomi Islam IAIN Sultan Maulana Hasanuddin Banten. 